\title{
PENGARUH LIKUIDITAS DAN LEVERAGE TERHADAP PROFITABILITAS PADA PERUSAHAAN SUB SEKTOR INDUSTRI BARANG KONSUMSI YANG TERDAFTAR DI BURSA EFEK INDONESIA
}

\author{
Oleh : \\ Cindya Tria Tanzil \\ S1 Manajemen \\ Darwin Lie, Efendi, Julyanthry
}

Abstraksi

Adapun rumusan masalah penelitian ini adalah bagaimana pengaruh likuiditas dan leverage terhadap profitabilitas pada perusahaan Sub Sektor Industri Barang Konsumsi yang terdaftar di Bursa Efek Indonesia. Metode yang digunakan dalam penulisan ini adalah penelitian kepustakaan dan penelitian lapangan. Data yang digunakan adalah data kualitatif dan data kuantitatif, dan teknik pengumpulan data yang digunakan adalah metode dokumentasi. Kemudian teknik analisis data menggunakan metode deskriptif kualitatif dan metode deskriptif kuantitatif.

Hasil penelitian dapat disimpulkan sebagai berikut:1. Rata-rata current ratio sebesar $218,90 \%$, rata-rata debt to assets ratio sebesar $44,55 \%$, dan rata-rata return on assets sebesar $8,56 \%$. 2 . Hasil regresi linier berganda, yaitu $\hat{Y}=5,788+0,044 X_{1}-0,130 X_{2}$, Likuiditas berpengaruh positif terhadap profitabilitas sementara leverage berpengaruh negatif terhadap profitabilitas pada Sub Sektor Industri Barang Konsumsi yang terdaftar di Bursa Efek Indonesia periode 2011-2016 3. Hasil analisis koefesien korelasi $r=0,823$ menyatakan bahwa terdapat hubungan yang sangat kuat antara likuiditas dan leverage dengan profitabilitas. Koefisien determinasi adalah sebesar 0,677. Artinya bahwa likuiditas dan leverage dapat menjelaskan profitabilitas sebesar $67,7 \%$. 4. Hasil uji hipotesis, $\mathrm{H}_{0}$ ditolak artinya likuiditas dan leverage berpengaruh signifikan terhadap profitabilitas pada Sub Sektor Industri Barang Konsumsi baik secara simultan maupun parsial.

Kata Kunci : Likuiditas, Leverage dan Profitabilitas

\section{Abstraction}

The formulation of this research problem is how the influence of liquidity and leverage to profitability in company of pharmacy which is enlisted on the Indonesia Stock Exchance. The method used in this paper is literature research and field research. The data used are qualitative data and quantitative data, and data collection techniques used documentation method. Then the technique of data analysis using qualitative descriptive method and quantitative descriptive method.

This result of this result can be summarized as follows: 1 . The average current ratio amount is $218,90 \%$, the average debt to assets ratio $44,55 \%$, and the average return on assets $8,56 \%$. 2 . The test result of multiple linear regression is $\hat{Y}=5,788+0,044 X_{1}-0,130 X_{2}$, mean that liquidity positive effect and leverage a negatife effect on profitability in Sub-sector of Consumer Goods Industry which listed on the Indonesia Stock Exchange. 3. The result of the analysis of the correlation coefficient states $r=0,823$ that there is high correlation between liquidity and leverage on profitability. The coefficient of determination states that liquidity and leverage have effect of $67,7 \%$ on profitability .4. the testing hypothesis, $H_{0}$ is rejected, mean that the liquidity and leverage have significant effect on profitability at Sub-sector of Consumer Goods Industry which listed on the Indonesia Stock Exchange either simultaneously or partially.

Keywords $\quad$ : Liquidity, Leverage and Profitability

\section{A. PENDAHULUAN}

\section{Latar Belakang Masalah}

Setiap perusahaan memiliki tujuan untuk mencari profitabilitas. kelangsungan hidup suatu perusahaan tergantung dari kemampuan perusahaan dalam menghasilkan profit atau laba perusahaan tersebut. Profitabilitas sangat penting bagi setiap pengguna laporan keuangan, khususnya investor, dan kreditor. Bagi investor laba merupakan satusatunya faktor penambahan nilai perusahaan. Bagi kreditor, laba merupakan sumber pembayaran bunga dan pajak
Besarnya profitabilitas dapat digunakan untuk menilai hasil kinerja perusahaan. Profitabilitas merupakan faktor yang harus mendapatkan perhatian karena untuk dapat melangsungkan hidupnya, suatu perusahaan harus berada dalam keadaan yang menguntungkan. Tanpa adanya keuntungan (profit), maka akan sulit bagi perusahaan untuk menarik para investor. Rasio profitabilitas yang digunakan dalam penelitian ini adalah return on assets (ROA). Return on assets merupakan rasio untuk mengukur kemampuan perusahaan dalam menghasilkan laba mengunakan 
asetnya. Penulis menggunakan rasio tersebut untuk mengetahui kemampuan perusahaan dalam menggunakan aset untuk menghasilkan laba.

Berikut ini adalah gambaran umum return on asset pada perusahaan sub sektor Industri Barang Konsumsi yang tercatat di Bursa Efek Indonesia periode 2011 sampai dengan 2016 yang dapat dilihat pada tabel 1 .

Tabel 1

Gambaran Umum Return On Asset pada

Perusahaan Sub Sektor Industri Barang

Konsumsi yang Terdaftar di Bursa Efek Indonesia Periode 2011-2016

\begin{tabular}{|c|c|c|c|c|c|c|c|}
\hline \multirow{2}{*}{ NAML PERUSHALA } & \multicolumn{6}{|c|}{ ROA/W } & \multirow{2}{*}{$\begin{array}{l}\text { RATAPATIA } \\
\text { ROA } \\
\text { (A) }\end{array}$} \\
\hline & 2011 & $w 2$ & wis & 2014 & 2015 & 216 & \\
\hline 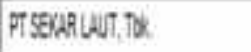 & 278 & 319 & 3.79 & $4 h$ & 532 & 300 & 394 \\
\hline PFUNORANDLA TD. & 13 & 19 & 10.5 & 35 & 110 & 1075 & 188 \\
\hline 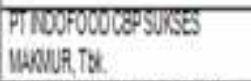 & 1357 & 12.6 & 1051 & 1028 & 10,51 & 125 & 11,71 \\
\hline 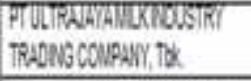 & 485 & $146 \%$ & 118 & 971 & 147 & 1674 & 1211 \\
\hline NOOFOCOSUKSESILWUR,TK & 913 & 106 & 43 & $5 \%$ & 404 & 644 & 64 \\
\hline PATASATAPERTARIN & 1,A & 15, & $B D$ & 69 & 9,13 & 10,2 & 155 \\
\hline
\end{tabular}

\section{Sumber Laocran Keuangan Perusahaan Sub Sektor housti Barang}

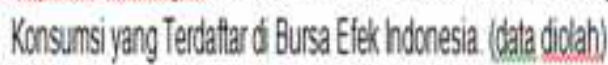

Berdasarkan tabel 1 di atas dapat dilihat bahwa rata-rata ROA pada periode 2011 sampai dengan 2016 sub sektor Industri Barang Konsumsi fluktuasi dan cenderung meningkat. Pada tahun 2013 ke 2014 rata-rata per tahun ROA mengalami penurunan dari $8,23 \%$ menjadi $6,97 \%$, namun pada tahun 2014 ke 2015 ROA mengalami peningkatan dari $6,97 \%$ menjadi $9,13 \%$ demikan juga dengan tahun-tahun berikutnya. Hal ini tidak sejalan dengan pendapat Horne dan John (2012:323), likuiditas perusahaan berbanding terbalik dengan profitabilitas. Maksudnya, semakin tinggi likuiditas perusahaan maka kemampuan perusahaan untuk menghasilkan laba semakin rendah.

\section{Rumusan Masalah}

a. Bagaimana gambaran likuiditas, leverage, dan profitabilitas pada Perusahaan Sub Sektor Industri Barang Konsumsi yang terdaftar di Bursa Efek Indonesia.

b. Bagaimana pengaruh likuiditas dan leverage terhadap profitabilitas pada Perusahaan Sub Sektor Industri Barang Konsumsi yang terdaftar di Bursa Efek Indonesia baik secara simultan maupun parsial.

\section{Tujuan Penelitian}

a. Untuk mengetahui gambaran likuiditas, leverage dan profitabilitas pada Perusahaan Sub Sektor Industri Barang Konsumsi yang terdaftar di Bursa Efek Indonesia.

b. Untuk mengetahui pengaruh likuiditas dan leverage terhadap profitabilitas pada Perusahaan Sub Sektor Industri Barang Konsumsi yang terdaftar di Bursa Efek Indonesia baik secara simultan maupun parsial.

\section{Metodologi Penelitian}

Dalam penelitian ini, penulis mengambil objek penelitian pada Sub Sektor Industri Barang Konsumsi yang tercatat di Bursa Efek Indonesia. Namun untuk memperoleh data yang dibutuhkan penulis mengakses data melalui website http://www.idx.co.id.

Desain penelitian yang digunakan dalam penulisan penelitian ini adalah penelitian kepustakaan (library research). Teknik analisa data yang digunakan dalam penelitian ini adalah Uji Asumsi Klasik, Analisa Deskriptif Kualitatif, Analisa Deskriptif Kuatitatif.

\section{B. LANDASAN TEORI}

1. Manajemen Keuangan

Menurut Keown, et, al. (2008:4), manajemen keuangan berkepentingan dengan bagaimana cara menciptakan cara dan menjaga nilai ekonomis atau kekayaan. Menurut Horne dan John (2012:2), manajemen keuangan adalah segala aktivitas yang berhubungan dengan perolehan aset, pendanaan dan manajemen aset yang didasari beberapa tujuan.

\section{Laporan Keuangan}

Menurut Kasmir (2010:66), secara umum diketahui bahwa laporan keuangan adalah laporan yang menunjukkan kondisi keuangan perusahaan pada saat ini atau dalam periode tertentu. Sedangkan menurut Brigham dan Joel (2010:86), laporan keuangan melaporkan apa yang sebenarnya terjadi pada asset, laba dan dividen selama beberapa tahun terakhir.

\section{Rasio Keuangan}

Menurut Kasmir (2010:93), rasio keuangan merupakan kegiatan membandingkan angka-angka yang ada dalam laporan keuangan dengan cara membagi satu angka dengan angka lainnya. Menurut Horne dan John (2012:163), rasio keuangan merupakan indeks yang menghubungkan dua angka akuntansi dan diperoleh dengan membagi satu angka dengan angka lainnya.

\section{Likuiditas}

Menurut Sudana (2011:21), rasio likuiditas (liquidity ratio) yaitu rasio yang mengukur kemampuan perusahaan untuk memenuhi kewajiban keuangan jangka pendek. Menurut Kasmir (2010:110), rasio likuiditas (liquidity ratio) merupakan rasio yang menggambarkan kemampuan perusahaan memenuhi kewajiban (hutang jangka pendek). 
Sedangkan menurut Brigham dan Joel (2010:134), rasio likuiditas disebut sebagai asset likuid (liquit assets).

\section{Leverage}

Menurut Kasmir (2010:112), rasio solvabilitas atau leverage merupakan suatu rasio yang digunakan untuk mengukur sejauh mana aktiva perusahaan dibiayai dengan utang. Menurut Sudana (2011:20), rasio leverage digunakan untuk mengukur seberapa besar penggunaan utang dalam pembelanjaan perusahaan.

Sedangkan menurut Halim (2007:64), leverage adalah penggunaan aset atau dana, dimana atas penggunaan tersebut perusahaan harus menanggung beban tetap berupa penyusutan atau berupa bunga.

\section{Profitabilitas}

Menurut Kasmir (2010:115), rasio profitabilitas merupakan rasio untuk memiliki kemampuan perusahaan dalam mencari keuntungan. Menurut Brigham dan Joel (2010:89), mengatakan bahwa profitabilitas adalah hasil bersih dari serangkaian kebijakan dan keputusan.

Sedangkan menurut Horne dan John (2012:176), rasio keuntungan atau profitability ratio pada prinsipnya menunjukkan seberapa mampu perusahaan dalam menghasilkan laba, baik dari penjualan yang ada maupun dari aset total yang dimiliki.

\section{Pengaruh Likuiditas dan Leverage \\ Terhadap Profitabilitas}

Rasio utang dalam sebuah laporan keuangan menunjukkan seberapa besar aset yang dibiayai dengan menggunakan utang. Rasio ini menekankan pada peran penting pendanaan utang bagi perusahaan dengan menunjukkan persentase aktiva perusahaan yang didukung oleh pendanaan utang (Horne dan John, 2012:182). Dengan mengetahui seberapa besar persentase utang yang dimiliki, perusahaan dapat mencegah terjadinya gagal bayar. Menurut Horne dan John (2012:323), likuiditas perusahaan berbanding terbalik dengan profitabilitas. Maksudnya, semakin tinggi likuiditas perusahaan maka kemampuan perusahaan untuk menghasilkan laba semakin rendah.

Berdasarkan signaling theory perusahaan yang mampu menghasilkan laba cenderung meningkatkan jumlah utangnya, karena tambahan pembayaran bunga akan diimbangi dengan laba sebelum pajak (Sudana, 2011:153).

\section{PEMBAHASAN}

1. Analisis

a. Analisis Deskripsi Kualitatif

Analisis deskriptif dalam penelitian ini bertujuan untuk mendapatkan gambaran atau deskripsi mengenai likuiditas, leverage dan profitabilitas pada perusahaan Sub Sektor Industri Barang Konsumsi yang terdaftar di Bursa Efek Indonesia periode 2011-2016

1) Gambaran Likuiditas pada Perusahaan Sub Sektor Industri Barang Konsumsi

Likuiditas merupakan kemampuan perusahaan untuk membayar semua kewajiban jangka pendek pada saat jatuh tempo, atau dengan kata lain kemampuan perusahaan untuk menyelesaikan kewajiban jangka pendeknya. Tingkat likuiditas memberikan gambaran tentang kemampuan perusahaan dalam membayar hutang-hutang jangka pendeknya, sehingga dapat menilai keamanan atas dana yang akan diinvestasikan. Pentingnya likuiditas dapat dilihat dengan mempertimbangkan dampak dari ketidakmampuan perusahaan memenuhi kewajiban jangka pendeknya

Data hasil penelitian likuiditas yang diukur dengan current ratio (CR) pada perusahaan sub sektor industri barang konsumsi yang terdaftar di Bursa Efek Indonesia periode 2011-2016 disajikan dalam Tabel 2.

Tabel 2

Current Ratio (CR) pada Perusahaan Sub Sektor Industri Barang Konsumsi yang terdaftar di Bursa Efek Indonesia Periode 2011-2016

\begin{tabular}{|c|c|c|c|c|}
\hline PERUSARCaN & TAHUN & ASET LANCAR & $\begin{array}{l}\text { KEWAIEAK } \\
\text { LANCAR }\end{array}$ & $\begin{array}{l}C R \\
\text { (N) }\end{array}$ \\
\hline \multirow{6}{*}{ PT SEKLR LAUT, TIK } & 2011 & 168.144724 .612 & 61944.022033 & 169,74 \\
\hline & 2012 & $125,655.521 .793$ & 81924,705832 & 141,4 \\
\hline & 2013 & 190.108 .112 .006 & 128.712 .112 .019 & 123,30 \\
\hline & 2014 & $167.419 .411,740$ & 141.425 .302223 & 118.39 \\
\hline & 2018 & 129.768 919.621 & $109132 \mathrm{a} 242277$ & 11928 \\
\hline & 2016 & 222.685 .372 .652 & 160.302 .512 .936 & $13 ! 32$ \\
\hline \multirow{6}{*}{ 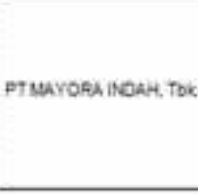 } & 2011 & 4995258708991 & 1843.791716 .900 & $2218 \pi$ \\
\hline & 2012 & 5313.580650516 & 1924.634110144 & 270.11 \\
\hline & 2013 & 6430.085 .281771 & 2.011 .500 .400 .622 & 24434 \\
\hline & 2014 & 6500.746 .623 .40 & 3114.337 .601 .362 & 200.90 \\
\hline & 2015 & $7454,347,029.087$ & 2.151 .455102654 & 29653 \\
\hline & 2016 & 6.739.7202750.141 & 3.854.05E:313 005 & 22802 \\
\hline \multirow{6}{*}{$\begin{array}{c}\text { PT MOOFOOD CBF } \\
\text { SUKSES } \\
\text { MKNMUA, ToK }\end{array}$} & 2011 & $1500,311,000050$ & 2.998 .5400000 .000 & 207,11 \\
\hline & 2012 & 3.058 .400 .050 .0200 & 3.579 .4670000000 & 270.25 \\
\hline & 2013 & 11321,715000000 & 4696.589000 .000 & 241.04 \\
\hline & 2014 & 13.005 .52 .0000000 & 0.230 .997 .000 .000 & 218.21 \\
\hline & 2015 & $12.961,500,000000$ & 6.902344000 .000 & 232.50 \\
\hline & 2010. & $18.571,300000000$ & 0.458 .752000 .000 & 240,88 \\
\hline \multirow{6}{*}{ 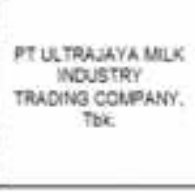 } & 2011 & $824.00023 n 1054$ & 607.594 .251 .942 & 132.09 \\
\hline & 2012 & 1996.438023 .543 & 592.922 .629 .143 & 201.25 \\
\hline & 2011 & 1.508510 .658 .134 & 6217940530008 & 247,01 \\
\hline & 2014 & 1542.101 .745 .19 & 498967.999 .228 & 334,45 \\
\hline & 2015 & 2103.564051 .027 & 551.628 .778 .382 & 124,50 \\
\hline & 2015 & 2.874 .027 .874 .013 & 592.5255991 .594 & $494 \times 3$ \\
\hline \multirow{6}{*}{ 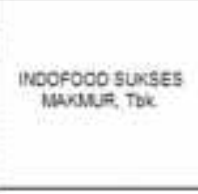 } & 2011 & 24.501 .734 .000000 & $12253: .004 .0000000$ & 130.35 \\
\hline & 2012 & 2.0202 .0202000500 & $12.000 .544,000000$ & 200.92 \\
\hline & 2013 & $32.40<450.000000$ & 19.471 .309 .0005000 & 160,73 \\
\hline & 2014 & 42.995 .756 .0009000 & 22091000.00000 & 190.74 \\
\hline & 2018 & 12.810 .700 .000000 & 25.107 .025 .0000000 & 170.53 \\
\hline & 2015 & $28.985 .40 \mathrm{cos} 000$ & $1921941 . \mathrm{mmam}$ & \\
\hline
\end{tabular}

Sumber: Data diolah (www.idx.co.id)

Berdasarkan tabel 2 di atas terlihat bahwa likuditas perusahaan pada sub sektor industri barang konsumsi berfluktuasi. Pada PT Sekar Laut, Tbk cenderung mengalami penurunan hal ini dapat dilihat dari rasio 
current ratio yang mengalami penurunan, demikian hal dengan PT Mayora, Tbk, PT Indofood CBP Sukses Makmur, Tbk, Indofood Sukses Makmur, Tbk. Hal ini dikarenakan peningkatan utang lancar perusahaan yang tidak diikuti oleh peningkatan aset lancar. Pada perusahaan Ultrajaya Milk Industry Tranding Company, Tbk mengalami peningkatan, hal ini terjadi karena peningkatan aset lancar tidak diikuti oleh peningkatan utang lancar perusahaan.

\section{2) Gambaran Umum Leverage pada Perusahaan Sub Sektor Industri Barang Konsumsi yang Terdaftar di Bursa Efek} Indonesia

Leverage merupakan rasio untuk mengukur seberapa banyak perusahaan menggunakan hutang. Rasio leverage digunakan untuk mengukur seberapa besar penggunaan utang dalam pembelanjaan perusahaan. Penggunaan leverage yang semakin besar membawa dampak positif bila pendapatan yang diterima dari penggunaan dana tersebut lebih besar dari pada beban keuangan yang dikeluarkan dan dampak negatif bila penggunaan leverage yang semakin besar akan menyebabkan hutang semakin besar.

Salah satu rasio yang digunakan untuk mengukur leverage yaitu Debt to Assets (DAR). Rasio ini digunakan untuk menunjukkan pengukur tingkat penggunaan utang (total hutang) terhadap aset yang dimiliki perusahaan. Selain itu penggunaan utang dalam pembiayaan kegiatan operasional, terlalu banyak dianggap tidak sehat karena dapat menurunkan laba disebabkan penggunaan utang akan menimbulkan beban bunga. Leverage adalah alat untuk mengukur sampai seberapa besar perusahaan dibiayai oleh utang. Debt to Asset Ratio (DAR) adalah indikator leverage yang digunakan dalam penelitian ini, rasio ini digunakan untuk mengetahui seberapa besar proporsi hutang dengan aset.

Data hasil penelitian leverage yang diukur dengan Debt to Assets (DAR) perusahaan sub sektor industri barang konsumsi yang terdaftar di Bursa Efek Indonesia periode 2011-2016 disajikan dalam berikut ini:

Tabel 3

Leverage pada Perusahaan Sub Sektor Industri Barang Konsumsi yang Terdaftar di Bursa Efek Indonesia

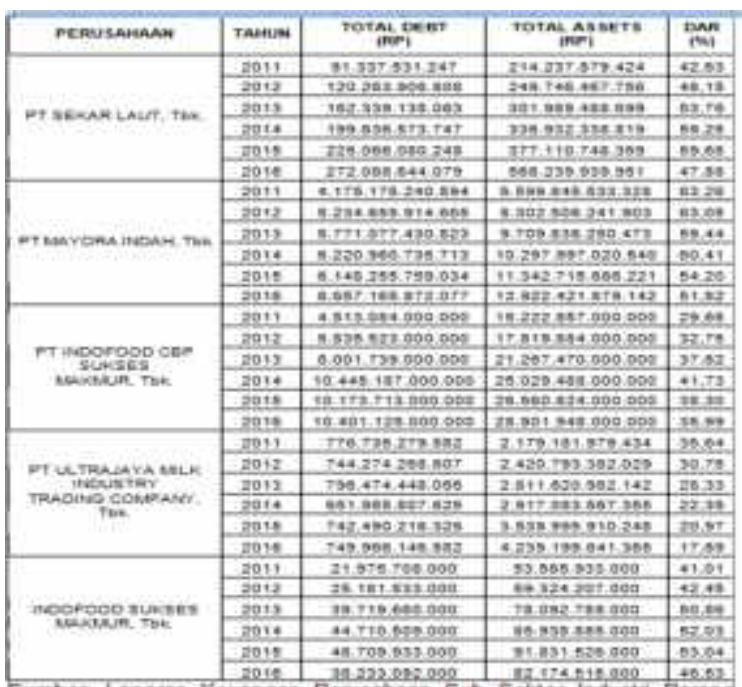

Sumber: Data diolah (www.idx.co.id)

Berdasarkan table 3 di atas terlihat bahwa leverage perusahaan pada sub sektor industri barang konsumsi berfluktuasi. Pada Ultrajaya Milk Industry Tranding Company, Tbk dan PT Mayora, Tbk cenderung mengalami penurunan. Hal ini dapat dilihat pada rasio debt to assets ratio pada PT Mayora, Tbk pada tahun 2011 sampai dengan tahun 2016 yang mengalami penurunan. Hal ini dikarenakan peningkatan aset perusahaan yang tidak diikuti oleh peningkatan utang, dapat dikatakan perusahaan mengurangi pengunaan utang dalam meningkatkan aktifitas perusahaan.

Pada perusahaan PT Sekar Laut, Tbk, PT Indofood CBP Sukses Makmur, Tbk, PT Indofood Sukses Makmur, Tbk mengalami peningkatan, hal ini terjadi karena peningkatan utang tidak diikuti oleh peningkatan aset perusahaan. Seperti pada PT Sekar Laut, Tbk pada tahun 2012 ke 2013 di saat utang perusahaan meningkat sebesar 25,92\% (Rp 120.263.906.808 menjadi Rp 162.339135063) aset perusahaan hanya meningkat sebesar $17,30 \%$ (Rp 249.746.467.756 menjadi $R p$ 301.989.488.699).

3) Gambaran Umum Profitabilitas pada Perusahaan Sub Sektor Industri Barang Konsumsi yang Terdaftar di Bursa Efek Indonesia

Profitabilitas adalah kemampuan suatu perusahaan untuk menghasilkan laba pada suatu periode tertentu. Laba sering kali menjadi salah satu ukuran kinerja perusahaan. Profitabilitas bagi perusahaan adalah kemampuan menggunakan sumber-sumber secara efisien dan memperoleh laba yang besar sehingga perusahaan tidak akan mengalami kesulitan mengembalikan hutanghutangnya baik hutang jangka pendek maupun hutang jangka panjang. Profitabilitas bertujuan untuk mengukur efektifitas manajemen melalui kegiatan perusahaan dengan kata lain mengukur kinerja perusahaan. 
Salah satu rasio yang digunakan untuk mengukur profitabilitas yaitu Return on Assets (ROA). Rasio ini juga memberikan tingkat efektivitas manajemen suatu perusahaan. Semakin tinggi nilai Return on assets (ROA) berarti kemampuan perusahaan menghasilkan laba atas aset sendiri semakin tinggi. Hal ini berarti profitabilitas perusahaan akan dikatakan baik apabila perusahaan mampu memberikan tingkat pengembalian yang tinggi.

Data hasil penelitian profitabilitas yang diukur dengan Return on Assets (ROA) perusahaan sub sektor industri barang konsumsi yang terdaftar di Bursa Efek Indonesia periode 2011-2016 disajikan dalam Tabel 4.

Tabel 4

Profitabilitas Pada Perusahaan Sub Sektor Industri Barang Konsumsi yang Terdaftar di Bursa Efek Indonesia

\begin{tabular}{|c|c|c|c|c|}
\hline РЕЯUSAYAaK & TANUN & $\begin{array}{l}\text { Earwing Ahor } \\
\text { Taxes } \\
\text { FFi }\end{array}$ & $\begin{array}{l}\text { TOTAC ASSETS } \\
\text { PAP? }\end{array}$ & R⿴囗十) \\
\hline \multirow{6}{*}{ PT SEKARLAUT, TDE. } & 2011 & 5.976730919 & 214237979424 & 2.79 \\
\hline & 2012 & 7.962 .09371 & 249.748 .467 .756 & 1.79 \\
\hline & 2011 & $11 .+45014.1111$ & 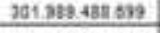 & 1.70 \\
\hline & 2014 & 16.410 .716 .354 & $230.932338 \pm 19$ & t.he \\
\hline & 2015 & 20.058791 .445 & $377+10746: 299$ & 5.32 \\
\hline & 2016 & 20.666 .721 .074 & ses. 23:933 351 & 2.63 \\
\hline \multirow{6}{*}{ FTMAYCRA MDLH TOK } & 2011 & 413.468152677 & 8.599.545.52 221 & 7,33 \\
\hline & 2012 & $744,428,40+309$ & 8302.500 .241903 & 8.97 \\
\hline & 2013 & 1.005438509282 & 9709.839250 .474 & 10.92 \\
\hline & 2014 & 409.824 .768 .594 & 10.297 .357000540 & 3.98 \\
\hline & 2015 & 1.200 .233121000 & $11.342 .755,000221$ & 11.02 \\
\hline & 2010 & 1388.078127505 & 12.82242187210 & 10.78 \\
\hline \multirow{6}{*}{ 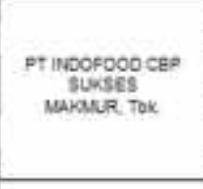 } & 2011 & 2000300000000 & $15.222355,500000$ & 13,57 \\
\hline & 2012 & 2287742000000 & $17.8+3.504 .0000000$ & 12.84 \\
\hline & 2013 & 2.235000000000 & 21.207 .400 .9000000 & 10,81 \\
\hline & 2014 & $2.974+172000000$ & 20.029 .458 .0009000 & 10,28 \\
\hline & 2015 & 29291480000000 & 28.560 .024 .000000 & 11,01 \\
\hline & 2014 & 3631.901 .000000 & 21.901568000900 & 12.58 \\
\hline \multirow{6}{*}{ 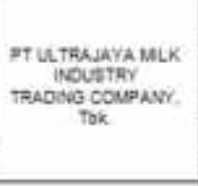 } & 2011 & 100.323 .273 .593 & 2.179 .181 .979 .454 & 11,55 \\
\hline & 2012 & 353.431 .512 .495 & 2420.793 .382 .029 & 14,6a \\
\hline & 2013 & $325+27.420 .544$ & 2ant 520302.142 & 15.55 \\
\hline & 2014 & 23.360914211 & 2311.13237435 & $9 \pi 1$ \\
\hline & 2015 & 523.100215029 & 1439.950910 .249 & 14.71 \\
\hline & 2014 & 709.895635 .742 & 4239.132541365 & 15.74 \\
\hline \multirow{6}{*}{$\begin{array}{l}\text { MOOFOOD Sunstes } \\
\text { Maratke Tok }\end{array}$} & 2011 & 4.091 .6730000 & 293555933.000 & 9.13 \\
\hline & 2012 & 4773445050 & 331324207.090 & 2.05 \\
\hline & 2013 & $3+160300000$ & 70.092700 .050 & 4.30 \\
\hline & 2014 & 5. 1452230000 & 19.930.ans.000 & 5.99 \\
\hline & 2015 & 2.701 .901 .050 & 21031520.050 & 4.04 \\
\hline & 2016 & $5.265906,000$ & 12174515.096 & 6,81 \\
\hline
\end{tabular}

Sumber: Data diolah (www.idx.co.id)

Berdasarkan tabel 4 di atas terlihat bahwa profitabilitas perusahaan pada sub sektor industri barang konsumsi berfluktuasi. Pada PT Indofood CBP Sukses Makmur, Tbk, PT Indofood Sukses Makmur, Tbk cenderung mengalami penurunan. Hal ini dapat dilihat dari rasio return on assets pada PT Indofood Sukses Makmur, Tbk yang mengalami penurunan dari tahun 2011 ke 2014 (13,57\%, $12,84 \%, 10,51 \%, 10,28 \%$ ). Hal ini dikarenakan penurunan kemampuan perusahaan dalam menghasilkan laba bersih menggunakan aset perusahan.

\section{b. Deskriptif Kuantitatif}

1) Regresi Linear Berganda
Pengujian analisis regresi berganda pada penelitian ini menggunakan SPSS versi 21 dengan hasil yang terlihat pada Tabel 5 .

Tabel 5

Hasil Analisis Regresi Linier Berganda Coefficients $^{a}$

\begin{tabular}{|c|c|c|c|c|}
\hline \multirow{2}{*}{\multicolumn{2}{|c|}{ Model }} & \multicolumn{2}{|c|}{$\begin{array}{l}\text { Unstandardized } \\
\text { Coefficients }\end{array}$} & \multirow{2}{*}{$\begin{array}{c}\begin{array}{c}\text { Standardized } \\
\text { Coefficients }\end{array} \\
\text { Beta }\end{array}$} \\
\hline & & B & $\begin{array}{l}\text { Std. } \\
\text { Error }\end{array}$ & \\
\hline \multirow[t]{3}{*}{1} & (Constant) & 5,788 & 2,611 & \\
\hline & CR & ,044 & ,008 & ,625 \\
\hline & TATO &,- 130 & ,034 &,- 423 \\
\hline
\end{tabular}

a. Dependent Variable: ROA

Sumber: Hasil Pengolahan (Output SPSS 21)

Berdasarkan hasil analisis dengan program SPSS pada tabel 5 di atas, Constant merupakan konstanta persamaan regresi. Sedangkan 0,069 dan -0,056 berturut-turut adalah konstanta untuk $X_{1}$ (likuiditas) dan $X_{2}$ (aktivitas). Sehingga apabila dituliskan, persamaan regresi linier berganda adalah sebagai berikut:

$$
\hat{Y}=5,788+0,044 X_{1}+0,130 X_{2}
$$

Dari hasil persamaan regresi di atas maka pengaruh likuiditas dan aktivitas terhadap profitabilitas dapat diinterpretasikan sebagai berikut:

1) $b_{0}=5,788$

Nilai konstanta sebesar 5,788 secara menunjukkan bahwa jika nilai variabel likuiditas dan aktivitas sama dengan nol maka nilai dari profitabilitas adalah sebesar 5,788 atau sebesar $57,88 \%$.

2) $b_{1}=0,044$

Koefisien regresi $b_{1}$ sebesar 0,044, menunjukkan bahwa setiap variabel likuiditas meningkat sebesar satu satuan maka akan meningkatkan profitabilitas sebesar 0,044 dengan asumsi variabel independen lainnya dianggap tetap atau sama dengan nol.

3) $b_{2}=0,130$

Koefisien regresi $b_{2}$ sebesar 0,130, menunjukkan bahwa setiap kenaikan variabel aktivitas sebesar satu satuan akan diikuti oleh penurunan profitabilitas sebesar 0,130 dengan asumsi variabel independen lainnya dianggap tetap atau sama dengan nol.

Dari persamaan regresi di atas, dapat disimpulkan bahwa likuiditas dan leverage memiliki pengaruh terhadap profitabilitas pada perusahaan Sub Sektor Industri Barang Konsumsi yang terdaftar di Bursa Efek Indonesia periode 2011-2016.

\section{2) Korelasi dan Koefisien Determinasi}

Berikut hasil pengolahan data yang menunjukkan korelasi dan determinasi pada Tabel 6. 
Tabel 6

Hasil Analisis Korelasi dan Koefisien Determinasi

Model Summary ${ }^{\circ}$

\begin{tabular}{l|c|r|r|r|r|}
\hline Model & $\mathbf{R}$ & $\begin{array}{c}\mathbf{R} \\
\text { Square }\end{array}$ & $\begin{array}{c}\text { Adjusted } \\
\mathrm{R} \\
\text { Square }\end{array}$ & $\begin{array}{c}\text { Std. Error } \\
\text { of the } \\
\text { Estimate }\end{array}$ & $\begin{array}{r}\text { Durbin- } \\
\text { Watson }\end{array}$ \\
\hline 1 & $\mathbf{8 2 3}^{\mathbf{a}}$ & $\mathbf{6 7 7 7}$ &, 653 & 2,15079 & 1,751 \\
\hline
\end{tabular}

Sumber: Hasil Pengolahan (Output SPSS 21)

Berdasarkan tabel 6 di atas diketahui bahwa nilai koefisien korelasi ( $r$ ) adalah sebesar 0,823 yang berarti hubungan antara likuiditas dan leverage terhadap profitabilitas pada perusahaan farmasi yang terdaftar di Bursa Efek Indonesia adalah sangat kuat. Sedangkan nilai koefisien determinasi $(R)$ adalah sebesar 0,677 yang berarti bahwa variasi variabel likuiditas dan leverage memiliki kekuatan $67,7 \%$ dalam mengestimasi profitabilitas, dengan kata lain profitabilitas dapat dijelaskan oleh likuiditas dan leverage sebesar $67,7 \%$ pada perusahaan farmasi yang terdaftar di Bursa Efek Indonesia dan sisanya sebesar $32,3 \%$ dijelaskan oleh variabel lain di luar variabel dalam penelitian ini seperti Quick Ratio, Working Capital Turnover (WCT), Return On Investment (ROI), dan efisiensi operasional.

\section{3) Uji Hipotesis}

\section{a) Uji Simultan (Uji F)}

Pengujian ini dilakukan secara simultan, yaitu dilakukan untuk menentukan diterima atau ditolaknya hipotesis. Jika $F_{\text {hitung }}>F_{\text {tabel }}$ atau signifikansi $\leq 0,05$, maka $\mathrm{H}_{0}$ ditolak.

Untuk menghasilkan suatu kesimpulan yang valid, maka harus dilakukan uji hipotesis dengan menggunakan program SPSS versi 19.

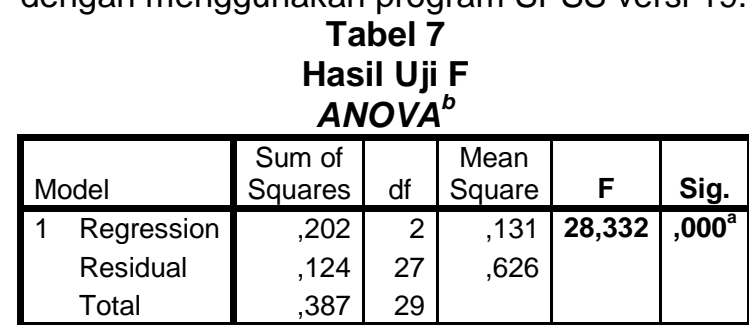

a. Predictors: (Constant), DAR, CR

b. Dependent Variable: ROA

Sumber: Hasil Pengolahan (Output SPSS 21)

Berdasarkan tabel 7 di atas dapat dilihat bahwa nilai $F_{\text {hitung }}$ sebesar 28,332 $>F_{\text {tabel }} 3,35$ dengan df pembilang $\mathrm{k}=2$, df penyebut (30-2$1=27$ ), dengan taraf signifikansi $0,000<0,05$, maka dapat disimpulkan bahwa likuiditas dan leverage berpengaruh signifikan terhadap profitabilitas pada perusahaan Sub Sektor Industri Barang Konsumsi yang terdaftar di Bursa Efek Indonesia periode 2011-2016.

\section{b) Uji Parsial (Uji t)}

Pengujian ini dilakukan secara parsial yang dilakukan untuk menentukan diterima atau ditolaknya hipotesis. Jika $t_{\text {hitung }}>t_{\text {tabel }}$ atau signifikansi $\leq 0,05$, maka $\mathrm{H}_{0}$ ditolak.

Tabel 8

Hasil Uji t

\begin{tabular}{|ll|l|l|}
\hline \multicolumn{1}{|c|}{ Model } & T & Sig. \\
& & \\
\hline 1 & (Constant) & 2,217 &, 035 \\
& CR & 5,600 &, 000 \\
TATO & $-3,787$ &, 001 \\
\hline
\end{tabular}

Sumber: Hasil Pengolahan (Output SPSS 21)

Berdasarkan tabel 8 di atas diperoleh hasil perhitungan, maka penulis dapat memberikan kesimpulan sebagai berikut:

a) $t_{\text {hitung }}>t_{\text {tabel }}(5,600>2,052)$ atau nilai signifikansi $0,000<0,05$, maka $\mathrm{H}_{0}$ ditolak yang berarti bahwa rasio likuiditas berpengaruh signifikan terhadap rasio profitabilitas pada perusahaan Sub Sektor Industri Barang Konsumsi yang terdaftar di Bursa Efek Indonesia periode 2011-2016.

b) $t_{\text {hitung }}<t_{\text {tabel }}(3,787>2,052)$ atau nilai signifikansi $0,001<0,05$, maka $\mathrm{H}_{0}$ diterima yang berarti bahwa rasio leverage berpengaruh signifikan terhadap rasio profitabilitas pada perusahaan Sub Sektor Industri Barang Konsumsi yang terdaftar di Bursa Efek Indonesia periode 2011-2016.

2. Evaluasi

a. Evaluasi Likuiditas pada Perusahaan Sub Sektor Industri Barang Konsumsi Yang Terdaftar di Bursa Efek Indonesia

Berdasarkan Tabel 2, ditunjukkan hasil current ratio maksimum yaitu mencapai $246,48 \%$, artinya bahwa kemampuan perusahaan untuk membayar hutang yang segera jatuh tempo dengan aktiva lancar adalah Rp.100 sedangkan hutang lancar dijamin oleh aktiva lancar sebesar Rp.246,48,-.

Dari hasil penelitian menunjukkan bahwa kondisi current ratio pada sub sektor industri barang konsumsi periode 2011-2016 berfluktuasi dan cenderung meningkat hal ini disebabkan oleh peningkatan aset lancar yang dimiliki oleh perusahaan dengan rata-rata rasio lancar pertahun sebesar $218,90 \%$. Terdapat tiga tahun di bawah rata-rata yaitu tahun 2011 , 2013, dan tahun 2014 hal ini kenaikan utang lancar yang dimiliki perusahan tidak diikuti kenaikan pada aktiva lancar dikatakan tidak signifikan dan tingkat kemampuan perusahaan untuk memenuhi kewajiban lancar tidak sesuai yang diharapkan.

b. Evaluasi Leverage pada Perusahaan Sub Sektor Industri Barang Konsumsi Yang Terdaftar di Bursa Efek Indonesia

Dari hasil penelitian menunjukkan bahwa kondisi Debt to Assets Ratio pada perusahaan sub sektor industri barang konsumsi berfluktuasi dan cenderung meningkat dari tahun ke tahun dengan hasil rata-rata akhir 
44,55\%. Jika dilihat dari perhitungan Debt to Assets Ratio pada Tabel 3 Debt to Assets Ratio pada tahun 2011 sampai dengan 2014 mengalami peningkatan sebesar $42,44 \%$, $43,43 \%, 46,00 \%$, dan $47,15 \%$ hal ini berarti setiap Rp.100 aset digunakan untuk menjamin Rp.42,44, Rp.43,43, Rp 46,00 dan Rp 47,15 total utang.

Penurunan total debt to total assets ratio perusahaan tahun 2014 sampai dengan 2016 sebesar 47,15\%, 45,24\%, 43,03\%, hal ini dikarenakan penurunan penggunaan utang yang digunakan oleh perusahaan pada sub sektor industri barang konsumsi. Semakin kecil rasio DAR menunjukkan bahwa sebagian besar investasi didanai dengan modal sendiri.

\section{c. Evaluasi Profitabilitas pada Perusahaan Sub Sektor Industri Barang Konsumsi Yang Terdaftar di Bursa Efek Indonesia}

Dari hasil penelitian menunjukkan bahwa kondisi Return on Assets pada sub sektor industri barang konsumsi yang terdaftar di Bursa Efek Indonesia berfluktuasi dan cenderung meningkat. Kondisi ini dapat terlihat pada Tabel 18 dimana nilai Return on Assets mengalami peningkatan yang cukup besar yang diakibatkan peningkatan laba bersih yang diperoleh oleh perusahaan.

Dari tabel 4 nilai rata-rata Return On Assets (ROA) sebesar $8,56 \%$ terdapat tiga tahun di bawah rata-rata yaitu pada tahun 2011, 2013, dan 2014, dimana total aset pada tahun 2012, 2011, 2013, dan 2014 mengalami kenaikan akan tetapi tidak diiringi dengan laba bersihnya yang mengalami penurunan yang mengakibatkan Return on Assets (ROA) menurun. Hal ini menunjukkan bahwa perusahaan belum secara maksimal dalam mengelolah asetnya untuk meningkatkan penjualan.

\section{KESIMPULAN DAN SARAN}

\section{Kesimpulan}

a. Rata-rata likuiditas (current ratio) yang dihasilkan pada perusahaan sub sektor industri barang konsumsi yang terdaftar di Bursa Efek Indonesia yaitu sebesar 218,90, artinya bahwa setiap Rp 100 hutang lancar dijamin oleh aktiva lancar sebesar Rp.218,90. Nilai maksimum current ratio sebesar $246,48 \%$ yang terdapat pada tahun 2016, dan nilai minimum current ratio sebesar $204,35 \%$ yang terdapat pada tahun 2011. Terdapat tiga tahun di bawah ratarata pada tahun 2011,2013 , dan 2014 . Hal ini menunjukkan bahwa belum mampunyai perusahaan mengelola aktiva lancarnya untuk menutup hutang lancarnya.

b. Rata-rata leverage yang dihasilkan pada perusahaan sub sektor industri barang konsumsi yang terdaftar di Bursa Efek Indonesia adalah sebesar $44,55 \%$, arti bahwa perusahaan menggunakan hutang sebesar $44,55 \%$ untuk mendanai aktivitas usahanya dibandingkan dengan asetnya dengan harapan dapat memaksimalkan keuntungan dan meminimalkan kerugian. Rata-rata debt to assets ratio (DAR) minimun sub sektor industri barang konsumsi periode 2011-2016 adalah sebesar $42,44 \%$ pada tahun 2011 . Hal ini disebabkan karena total kewajiban perusahaan memiliki jumlah yang lebih kecil dibanding aset perusahaan. Sedangkan nilai maksimum rata-rata debt to assets ratio (DAR) pada sub sektor industri barang konsumsi periode 2011-2016 adalah sebesar $47,15 \%$ pada tahun 2014 , hal ini disebabkan total kewajiban perusahaan memiliki jumlah yang lebih besar dibanding aset perusahaan.

c. Rata-rata profitabilitas yang dihasilkan pada perusahaan sub sektor industri barang konsumsi yang terdaftar di Bursa Efek adalah sebesar $8,56 \%$. Terdapat tiga thaun di bawah rata-rata yaitu pada tahun 2011 , 2013, dan 2014. Hal ini menunjukkan kinerja manajemen pada perusahaan bisa dikatakan kurang baik. rata-rata return on assets (ROA) minimun adalah sebesar 6,97\% pada tahun 2014. Hal ini disebabkan pada tahun 2014 terjadi penurunan laba bersih yang diperoleh perusahaan. Sedangkan nilai maksimum rata-rata return on assets (ROA) minimun pada sub sektor industri barang konsumsi periode 20112016 adalah sebesar $10,02 \%$ pada tahun 2016, hal ini disebabkan peningkatan laba bersih yang diperoleh perusahaan.

d. Model persamaan regresi adalah $\hat{Y}=\mathbf{5 , 7 8 8}$ $+\mathbf{0 , 0 4 4} X_{1}-\mathbf{0 , 1 3 0} X_{2}$. Menunjukkan bahwa likuiditas berpengaruh positif dan leverage berpengaruh negatif terhadap profitabilitas pada perusahaan sub sektor industri barang konsumsi yang terdaftar di Bursa Efek Indonesia periode 2011-2016.

e. Hubungan variabel $X_{1}(C R)$ dan $X_{2}$ (DAR) terhadap variabel $Y(R O A)$ yang dijelaskan pada koefisien korelasi dapat dilihat pada Tabel 6. Koefisien korelasi ( $r$ ) dalam penelitian ini sebesar 0,823 , artinya hubungan antara variabel $X_{1}(C R)$ dan $X_{2}$ (DAR) terhadap variabel $Y(R O A)$ dapat dikatakan sangat kuat pada sub sektor industri barang konsumsi yang terdaftar di Bursa Efek Indonesia. Untuk mengetahui besarnya pengaruh terhadap ketiga variabel diperoleh melalui uji koefisien determinasi (R Square). Dari hasil uji determinasi pada Tabel 6 dapat dilihat bahwa Current Ratio dan Debt to Assets Ratio mampu menjelaskan variabel Return on Assets sebesar $67,7 \%$, sedangkan $32,3 \%$ dapat dijelaskan oleh variabel lain yang tidak dibahas dalam penelitian ini, misalnya Days 
Sales Outsanding (DSO), Cash Ratio, Quick Ratio (QR) atau Working Capital Turnover (WCT) Debt to Equity Ratio (DER).

f. Dari hasil penelitian uji $F$, disimpulkan likuiditas dan leverage berpengaruh signifikan terhadap profitabilitas pada perusahaan sub sektor industri barang konsumsi yang terdaftar di Bursa Efek Indonesia secara simultan. Hal ditunjukkan dengan $F_{\text {hitung }} 28,332>F_{\text {tabel }} 3,35$ atau nilai sig $0,000<0,05$.

g. Hasil pengujian uji t disimpulkan bahwa bahwa likuiditas berpengaruh signifikan terhadap profitabilitas pada Perusahaan Sub Sektor Industri Barang Konsumsi yang terdaftar di Bursa Efek Indonesia. Hal ini ditunjukan untuk current ratio $\mathrm{t}_{\text {hitung }} 5,600>$ $t_{\text {tabel }} 2,052$ atau nilai sig $0,000<0,05$ Untuk variabel leverage berpengaruh signifikan terhadap profitabilitas pada Perusahaan Sub Sektor Industri Barang Konsumsi yang terdaftar di Bursa Efek Indonesia. Hal ditunjukan dengan $\mathrm{t}_{\text {hitung }} 3,787>\mathrm{t}_{\text {tabel }} 2,052$ atau nilai sig $0,001<0,05$.

\section{Saran}

a. Untuk mengoptimalkan likuiditas perusahaan harus meningkatkan jumlah aset yang dimilikinya. Perusahaan dapat mempertimbangkan dengan cara mengoptimalkan penagihan piutang usaha, serta mengendalikan pemakaian utang perusahaan.

b. Untuk mengomptimalkan leverage perusahaan bisa mempertimbangkan dengan mengurangi jumlah utang, baik pinjaman jangka panjang maupun jangka pendek. Perusahaan harus mampu mengendalikan penggunaan utang untuk pembeli bahan baku dan mengganti mesinmesin yang kurang produktif sehingga meningkatkan penjualan. Peningkatan penjualan dapat meningkatkan laba yang berdampak pada peningkatan profitabilitas perusahaan

C. Untuk mengoptimalkan profitabilitas, perusahaan sebaiknya meningkatkan net operating income. Perusahaan juga sebaiknya meningkatkan penjualan baik dengan cara meningkatkan volume penjualan, ataupun dengan menaikkan tingkat harga penjualan hal ini tergantung dengan kondisi pasar.

\section{E. DAFTAR PUSTAKA}

Brigham, Eugene $F$, dan Joel F. Houston. 2006. Dasar-Dasar Manajemen Keuangan, Buku 2, Edisi Kesepuluh. Jakarta : Salemba Empat.

Halim, Abdul. 2007. Manajemen Keuangan Bisnis. Bogor : Penerbit Ghalia Indonesia.

Horne, James C. Van and John. 2012. Prinsipprinsip Manajemen Keuangan. Edisi Ketigabelas, Jilid 1. Jakarta : Salemba Empat.

Kasmir. 2010. Pengantar Manajemen Perusahaan, Edisi Pertama, Cetakan Pertama. Jakarta : Kencana.

Keown, et. al. 2008. Manajemen Keuangan. Edisi 10. Jakarta : PT. Macanan Jaya Cemerlang.

Sudana. I Made. 2011. Manajemen Keuangan Perusahaan Teori dan Praktek. Jakarta : Penerbit Erlangga 